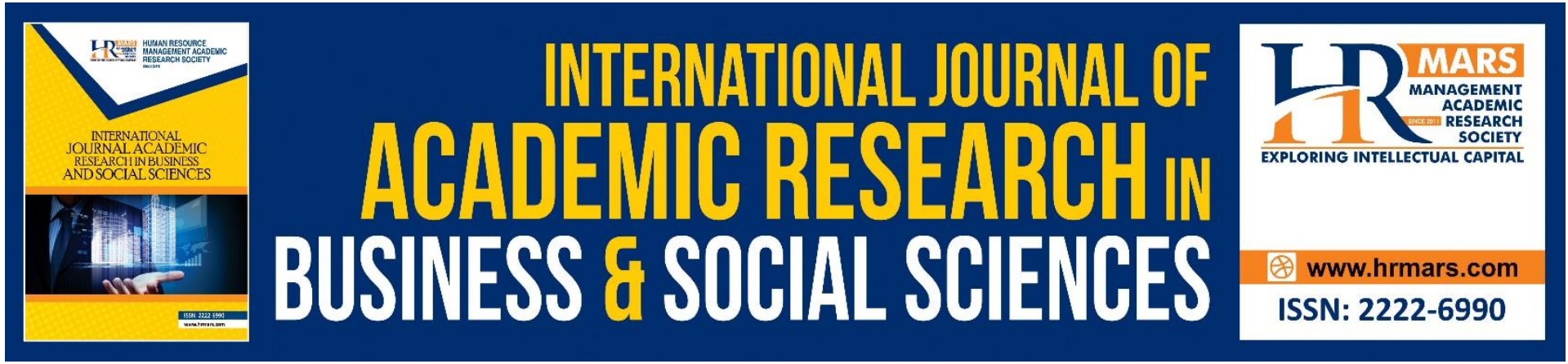

\title{
The Cross Over Process of Employees' Dedication on Visitors' Satisfaction using UWES Work Engagement Model: A Case on MAHA Expo 2018
}

Nor Azmawati Husain, Norlela Abas, Norshiba Norhisham \& Nurul Azrin Ariffin

To Link this Article: http://dx.doi.org/10.6007/IJARBSS/v11-i9/11110 DOI:10.6007/IJARBSS/v11-i9/11110

Received: 05 July 2021, Revised: 29 July 2021, Accepted: 21 August 2021

Published Online: 15 September 2021

In-Text Citation: (Husain et al., 2021)

To Cite this Article: Husain, N. A., Abas, N., Norhisham, N., \& Ariffin, N. A. (2021). The Cross Over Process of Employees' Dedication on Visitors' Satisfaction using UWES Work Engagement Model: A Case on MAHA Expo 2018. International Journal of Academic Research in Business and Social Sciences, 11(9), 1144-1158.

Copyright: (c) 2021 The Author(s)

Published by Human Resource Management Academic Research Society (www.hrmars.com) This article is published under the Creative Commons Attribution (CC BY 4.0) license. Anyone may reproduce, distribute, translate and create derivative works of this article (for both commercial and non-commercial purposes), subject to full attribution to the original publication and authors. The full terms of this license may be seen at: http://creativecommons.org/licences/by/4.0/legalcode

Vol. 11, No. 9, 2021, Pg. 1144 - 1158

Full Terms \& Conditions of access and use can be found at http://hrmars.com/index.php/pages/detail/publication-ethics 




\title{
The Cross Over Process of Employees' Dedication on Visitors' Satisfaction using UWES Work Engagement Model: A Case on MAHA Expo 2018
}

\author{
Nor Azmawati Husain ${ }^{1}$, Norlela Abas ${ }^{1}$, Norshiba Norhisham² \& \\ Nurul Azrin Ariffin ${ }^{3}$ \\ ${ }^{1}$ Department of Management \& Marketing, Faculty Business Management, University \\ Teknologi MARA UiTM Melaka Jasin Campus, Merlimau, Malaysia, ${ }^{2}$ Department of Human \\ Resource, Faculty Business Management, University Teknologi MARA UiTM Melaka City \\ Campus, Bandar Melaka Country, ${ }^{3}$ Department of International Business, Faculty Business \\ Management, University Teknologi MARA UiTM Melaka City Campus, Bandar Melaka \\ Country
}

Email: noraz462@uitm.edu.my,norlela192@uitm.edu.my, shibahisham@uitm.edu.my, nurulazrin@uitm.edu.my

\begin{abstract}
Mega events such as expo give valuable opportunities to visitors for them to experience the unique natures of presented themes. Malaysian Agriculture, Horticulture \& Agrotourism Show (MAHA) was organised annually in Malaysia with a based-theme of agriculture. In general, many factors has been considered in measuring visitor's satisfaction with regards to mega events such as expo. Visitors' satisfaction is crucial as this level of satisfaction affecting their experiential product hence change their whole experiences in visiting expo in future. The purpose of this study is to identify the association of job resources such as skill discretion and co-workers' support among employees at booths during the MAHA 2018 event crossover on visitor satisfaction, specifically through the Utrecht Work Engagement Scale (UWES) I(e.g. dedication and absorption). 99 onsite surveys were collected on employees and visitors at various booths at the MAHA 2018 event. Data was analysed using SPSS version 20 using multiple regression analysis. Main findings indicates that the dedication of employees mediates the relationship between skill discretion and visitor satisfaction.we also discovers dedication of employees at the expo do crossover to visitors and affect their satisfaction level as been predicted through the actor-partner independence model(APIM). This supports the notions of employees' work engagement, especially the aspect of dedication is crucial as this elements of work engagement has direct effect on visitors' satisfaction level. Further studies should focus on improving dedication of employees at expo as it has the marketing implication to attract more visitors in future.
\end{abstract}

Keywords: Work Engagement, Visitor Satisfaction, Dedication, Absorption, Job Resources 


\section{Introduction}

Over the years, trade shows and exhibitions have provided a smooth playing field in which small and large businesses come together to celebrate their effectiveness. According to Situma (2012), organizations constantly drawn into the economies of scale implementation when it comes to promote their products or services in which trade shows can give them exactly the marketing platform they are looking for. According to Scott, Si, Schumilas and Chen (2014), agriculture shows have existed since the late eighteen century and since then have evolved to be one of the most popular events with a constant growing number of attendees each year. For instance, one of the earliest agricultural shows, the Royal Lancashire Show which began in 1767, and the Royal Cornwall Show, now in its 222nd year as of 2017, were initially designed to showcase "best in breed" livestock. This soon developed into the highlight of the farming social calendar (Darian-Smith, 2011).

Originally, these agriculture events were mostly attended by farming families, livestock breeders and the associated companies and services in similar fields. Today, the diversity of the attendees such as consumers and anyone interested in joining the trade fairs have become more significant. Agricultural fairs offer an idyllic platform for educating the visitors and for them to "re-image "agriculture (Holloway, 2004). This can be linked with the changing consumer lifestyle relating to health, well-being and transparency in the food origins. Therefore, agriculture events must evolve in response to consumers' demand to ensure the longevity of their appeal. For example, the visitors have expressed desire to witness performances motivated by the exhibitors' care for the animals and for these visitors to get the chance to assess both, the business side, and on the community side of exhibiting farmers (Larsen, 2017)

One of the agriculture events, the Malaysia Agriculture, Horticulture and Agrotourism (MAHA), is organized by the Ministry of Agriculture and Food Industries where it aims at promoting agriculture and agro-based industries. The MAHA fair highlights efforts made by the government agencies, as well as presenting numerous business opportunities. For instance, approximately 2.7 million visitors attended the MAHA 2016 which was organized at The Malaysia Agro Exposition Park in Serdang (MAEPS), and the expected number of visitors for MAHA 2018 was roughly 3.5 million people. This indicates that visitors are interested in the agriculture shows that are offered as they help visitors broaden their knowledge and experiences in the field. Besides that, this agriculture expo focuses on emphasizing the importance of innovation and technology in the agriculture industry. Recently, the MAHA 2020 acted as a "game changer" in this new norm in which the event was conducted virtually as a platform that was specifically designed to fulfil the business needs of the agriculture and food industries. Various activities were available such as discussions, business connections, webinars, video conferencing, product displays and promotions by more than 700 exhibitors, either from domestic or international markets.

However, studies on the effectiveness of trade shows, particularly on the employeesvisitors' engagement have been neglected from a research perspective, despite the importance and popularity of these trade events worldwide. Work engagement can be described as a persistent and pervasive affective-cognitive state that is not focused on any particular object, event, individual or behaviour (Schaufeli \& Bakker, 2004, p. 295). Although the agricultural fairs have remained well-known annual events, surprisingly, there lacks rigorous academic literature and research devoted to understand the effects of work engagement on the workers at these expos on its visitors. The main purpose of this research is to examine the work engagement model and its influence towards the expo visitors' 
expectations. From the employees' perspective, satisfaction with job resources had a statistically significant positive influence on both dimensions of work engagement in which, this workplace practices that emphasize on care and respect and the job resources development will technically improve the work engagement. The engagement between the employees and the visitors at an expo or an exhibition is vital in a sense that the success of the event lies within them. This study aims at contributing to the in depth understanding from a new perspective of two sources of data such as dyad data from employees, as well as the visitors. It is considered common to study on the work engagement, however, specifically for this study, the researchers will explore more on the workers' engagement -visitor to further understand the visitors' satisfaction at an agricultural expo.

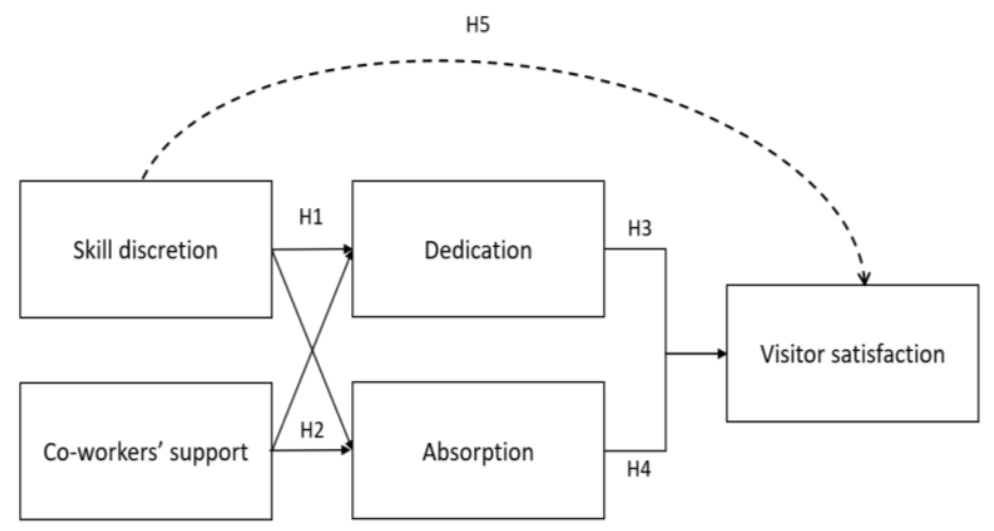

Figure 1: Proposed model

\section{Literature Review}

Job resources, as stated by Bakker and Demerouti (2007) are positive job characteristics that can reduce the negative effects of job demands and induce motivation on workers to achieved organizational goals. Bakker, Demerouti and Verbeke (2004) also argued that job resources are one of the main instruments in achieving work goals as well as stimulating personnel growth and development. Among the examples of job resources are employees who experience autonomy at work, have supportive colleagues, receive proper coaching and highquality feedback, and have opportunities for professional development. These possess the instrumental means for workers to be intrinsically motivated to achieve their work goals (Bakker \& Demerouti, 2007). Crawford, LePine and Rich (2010) in their reviews suggested that most job resources positively influence work engagement, and a few job demands (i.e., Hindrance job demand) significantly influence work engagement. Given the positive influence brought by work engagement, numerous studies were conducted in identifying the combinations of resources that can be used to develop engaged workers (Bakker et al., 2011).

The relationships between different types of resources and work engagement are best explained when all potential effects are simultaneously considered. Specifically, the current study shows that job resources influence work engagement reciprocally (Xanthopoulou, Bakker, Demerouti \& Schaufeli, 2009). For example, in the teaching profession, supervisor support, innovativeness, information, appreciation and organizational climate can all be considered important job resources as each of these conditions are able to buffer the negative impact of pupil misbehaviour on work engagement (Bakker et al, 2007). Hence, it is suggested that job resources should be ample enough to deal with the former job demands as a suitable fit between these two aspects are related to work engagement. This would further contribute 
positively to other organizational outcomes such as job satisfaction and engagement (Albrecht \& Anglim, 2018).

Work engagement is still the highlight of many organizational studies. In a study conducted by AL-Dubai, Qureshi, Ismail and Rampal (2012) reported that the overall level of work engagement was higher in Finland than in Russia. The opportunity to learn new skills at work was the strongest predictor of work engagement in both countries. The most significant difference was that once job demands and resources were taken into account, the managerial position had a strong effect on work engagement in Russia, while there were no such significant findings in Finland.

All job resources have a distinct effect on work engagement. Studies conducted by Allahyari et al (2008) suggested that co-workers' support and skill discretion positively correlated with the person organization (P-O) fit. Meanwhile, Arezes and Miguel (2008) in their study found that co-workers' support has a direct effect on Total Quality Management (TQM) implementation and organization performance. Co-workers' support is another source of social support that helps in managing and coping with the job demands and thus, increase job performance (Arnold et al., 2009).

Meanwhile another type of job resources known as skill discretion has been labelled as the degree of the workers making full use of their skills (Bailey, Gremler \& McCollough, 2001). This resource often receives less attention among scholars and little to be found established scales to represent skills can be found. Bakker, Demerouti and Euwema (2005) included skill discretion as the job resource in their study by establishing their own scale. Skill discretion is when the workers feeling benefited from the work and it improves his competency. Since skill discretion is not commonly tested as job resources among service workers (i.e., workers at expo), we incorporated both types of job resources to be tested in the model.

Work engagement are multidimensional measures that are comprised of several constructs namely vigour, dedication and absorption. Vigour refers to the high level of energy and mental resilience while working, dedication refers to being strongly involved in one's work and experiencing a sense of significance, enthusiasm and challenge, and lastly, absorption refers to being fully concentrated and happily engrossed in one's work (Bakker \& Demerouti, 2008, p. 210). In regard to this current study, only two constructs were used, which are dedication and absorption. One study conducted among Palestine University staff discovered that the dedication and absorption levels are high (82\%)(Bakker, 2014). Dedication refers to the strong embrace of the individual in his work, his sense of value and importance, as well as the feeling of enthusiasm, inspiration and challenge when practicing his work. It can become a primary barometer that significantly leads to job satisfaction and reduce turnover intentions compared to vigour and absorption (Bakker \& Bal, 2010). Absorption is argued to be influenced by many factors including job resources (Schaufeli \& Bakker, 2004), emotional stability (Barken et al., 2018) and many other potential factors. Absorption alone has a direct effect on various positive organizational outcomes such as job satisfaction (Barken et al., 2018).

The mediational roles of work engagement constructs (e.g., Dedication and absorption) have been discussed in several occupational contexts. For example, work engagement mediates the relationship between job resources and prosocial service behaviours among hotel staff in Taiwan (Bakker, 2009). Within group level, work engagement mediates the relationship between team resources and team performance among employees in Spain (Bianchi, Schonfeld \& Laurent, 2020). Meanwhile Biswas, Varma and Ramaswami 
(2013) in their study discovered that not every construct of work engagement possessed the mediational elements. They merely found support on the mediational roles of vigour and dedication on the relationship between job resources (i.e. coworkers' supports) and nurses' performances.

Scholars suggested a possible potential of a cross over mechanism occurring between the work engagement of an individual to another individual (Bakker \& Xanthopoulou, 2009). We expect one construct of work engagement that may have a cross over effect and influence on visitor satisfaction. The Actor Partner Independence Model (APIM) (Cook \& Kenny, 2005) was used in this current study where workers acted as actors, and visitors as partners. Conventionally, the study that concerns the satisfaction level of visitors to exhibitions often highlighted factors such as quality, emotions/moods (Bass, 1985), programme, souvenirs, food and facilities (Baxter, Lyndon, Dole \& Battistutta, 2004), whereas less focus was given to factors related to workers such as work engagement. Hence, we incorporated other factors to be considered as part of the determinant in visitors, thus postulating hypotheses below:

H1a: Skill discretion is positively associated with dedication

H1b: Skill discretion is positively associated with absorption

H2a: Co-workers' support is positively associated with dedication

H2b: Co-workers' support is positively associated with absorption

H3: Dedication is positively associated with visitors' satisfaction

H4: Absorption is positively associated with visitors' satisfaction

H5: Dedication mediates the relationship between skill discretion and visitors' satisfaction

\section{Methodology}

\section{Procedures and participants}

The research was conducted among a dyad of 99 workers and visitors who operated their booths during the MAHA 2018 event. The employees were requested to answer the survey by the enumerators that approached them during the event. Meanwhile, we also gathered the feedback from the visitors who visited their booths at the same time. Of the 150 surveys distributed, only 99 were able to complete the survey (66\% response rate).

\section{Instruments}

Skill discretion

The variable "Skill discretion" represented job resources for which four items were adopted from the Job Content Questionnaire (Karasek, 1979). The responses ranged from (1) "strongly disagree" to (4) "strongly agree". An example of a related question is: "My job requires me to learn new things". The reliability of the scale was acceptable $(\alpha=0.81)$.

\section{Coworkers' support}

The variable "Coworkers' support" represented job resources for which four items were adopted from the Job Content Questionnaire (Karasek, 1979). The responses ranged from (1) "strongly disagree" to (4) "strongly agree". An example of a related statement is: "People I work with are competent in doing their job". The reliability of the scale was acceptable $(\alpha=$ $0.75)$. 
Work Engagement

Work engagement was measured by using two constructs i.e., dedication $(\alpha=0.90)$ and absorption $(r=0.41, p<0.001)$ using the Utrech Work Engagement Scale (UWES) (Schaufeli, Salanova, González-romá \& Bakker, 2002). The scale ranged from (1) strongly disagree to (5) strongly agree. Examples of the statements are "I find my work full of meaning and purpose" and "When I am working, I forget everything else around me"

\section{Visitor's Satisfaction}

The variable "visitor satisfaction" measured the visitor outcome in this study. We adopted the questions from (Bitner \& Hubbert, 1994) which comprises of a 4-item scale. Examples of the related questions are: "I am very satisfied"; "I will encourage friends and relatives to visit the booth operated by this organization" and "I love to talk to my friends about how I am satisfied with the booth operated by this organization". The scale ranged from (1) "strongly disagree" to (5) "strongly agree". The reliability for this scale was acceptable $(\alpha=0.71)$.

\section{Analysis Strategy}

Descriptive and frequency information were derived to assess the representativeness of the sample. Bivariate correlation analysis was undertaken to delineate the relationship between job resources, work engagement and visitor satisfaction. The data were initially screened using descriptive statistics. We then used the IBM SPSS Statistics (SPSS) software package to see the inter-correlations between the variables. Through the exploratory factor analysis (EFA), we confirmed the reliability of the studied variables and the instruments where the KMO value is acceptable at 0.75 near to 1 . The next analysis is the multiple regression analysis to test the direct effect of each variable which includes the mediation effect. In order to see the mediation effect, we utilized the mediation test using the Monte Carlo simulation (Selig \& Preacher, 2008) 
Table 1: Exploratory factor analysis (EFA)

\begin{tabular}{|c|c|c|c|c|c|c|c|}
\hline & Factor & & & & & & \\
\hline & 1 & 2 & 3 & 4 & 5 & 6 & 7 \\
\hline ED3 & 0.93 & & & & & & \\
\hline ED4 & 0.842 & & & & & & \\
\hline ED2 & 0.838 & & & & & & \\
\hline ED1 & 0.812 & & & & & & \\
\hline SK6 & & 1.084 & & & & & \\
\hline SK4 & & 0.578 & & & & & \\
\hline SK5 & & 0.522 & & & & & \\
\hline SK1 & & 0.465 & & & & & \\
\hline DED2 & & & & 0.931 & & & \\
\hline DED1 & & & & 0.795 & & & \\
\hline DED3 & & & & 0.664 & & & \\
\hline CO1 & & & & & 1.065 & & \\
\hline $\mathrm{CO} 2$ & & & & & 0.459 & & \\
\hline $\mathrm{CO} 3$ & & & & & 0.374 & & \\
\hline PS3 & & & & & & 0.848 & \\
\hline PS1 & & & & & & 0.696 & \\
\hline PS2 & & & & & & 0.435 & \\
\hline AB3 & & & & & & & 0.903 \\
\hline AB2 & & & & & & & 0.722 \\
\hline
\end{tabular}

Extraction Method: Maximum Likelihood.

Rotation Method: Promax with Kaiser Normalization.

a. Rotation converged in 7 iterations.

Table 2: KMO values

KMO and Bartlett's Test

Kaiser-Meyer-Olkin Measure of Sampling Adequacy. $\quad 0.75$

\begin{tabular}{lll} 
& Approx. Chi-Square & 1078.887 \\
Bartlett's Test of Sphericity & df & 276 \\
& Sig. & 0 \\
\hline
\end{tabular}

\section{Discussion}

Table 3 shows the distribution of respondents for the study. There are 99 respondents for this study where among them are the workers at the MAHA Expo 2018. The majority of the respondents were aged $20-29$ years old (51.5\%), male (60.6\%) and of the Malay race $(89.7 \%)$. The workers possessed $0-9$ years of working experience $(71.4 \%)$ where some were in the management level of employment $(58.8 \%)$, in private sectors $(62.6 \%)$ as well as Diploma holders (42.4\%) in various industries (60.6\%). With regards to the visitors' profiles, both genders have equal interest in these events in which the percentage of male visitors is slightly higher (51.5\%) compared to the female visitors. 
Table 3: Demographic profile of the respondents (workers)

\begin{tabular}{|c|c|c|c|}
\hline & Category & No. of respondents & Percentage \\
\hline \multirow[t]{6}{*}{ Age } & $<19$ years old & 1 & 1.0 \\
\hline & $20-29$ years old & 51 & 51.5 \\
\hline & $30-39$ years old & 37 & 37.4 \\
\hline & $40-49$ years old & 9 & 9.1 \\
\hline & $50-59$ years old & 1 & 1.0 \\
\hline & $>60$ years old & 0 & 0.0 \\
\hline \multirow[t]{2}{*}{ Gender } & Male & 60 & 60.6 \\
\hline & Female & 30 & 39.4 \\
\hline \multirow[t]{2}{*}{ Status } & Single & 50 & 51.5 \\
\hline & Married & 47 & 48.5 \\
\hline \multirow[t]{4}{*}{ Race } & Malay & 87 & 89.7 \\
\hline & Chinese & 7 & 7.2 \\
\hline & Indian & 1 & 1.0 \\
\hline & Others & 2 & 2.1 \\
\hline \multirow[t]{3}{*}{ Experience } & $0-9$ years & 70 & 71.4 \\
\hline & $10-19$ years & 22 & 22.4 \\
\hline & $20-29$ years & 6 & 6.1 \\
\hline \multirow[t]{2}{*}{ Position } & Management level & 57 & 58.8 \\
\hline & Non-management level & 40 & 41.2 \\
\hline \multirow[t]{2}{*}{ Ownership status } & Government agencies & 37 & 37.4 \\
\hline & Private sectors & 62 & 62.6 \\
\hline \multirow[t]{4}{*}{ Education level } & SPM & 26 & 26.3 \\
\hline & Diploma & 42 & 42.4 \\
\hline & First Degree & 29 & 9.3 \\
\hline & Degree/PhD & 2 & 2.0 \\
\hline \multirow[t]{4}{*}{ Industry } & Food & 8 & 8.2 \\
\hline & Agriculture & 26 & 26.5 \\
\hline & Livestock & 4 & 4.1 \\
\hline & Others & 60 & 60.6 \\
\hline
\end{tabular}


Table 4: Demographic profile of the respondents (visitors)

\begin{tabular}{llll}
\hline & Category & No. of respondents & Percentage \\
\hline \multirow{4}{*}{ Gender } & Male & 50 & 51.5 \\
& Female & 47 & 48.5 \\
& $<19$ years old & 10 & 10.3 \\
& $20-29$ years old & 46 & 47.4 \\
& $30-39$ years old & 20 & 20.6 \\
\multirow{4}{*}{ Race } & $40-49$ years old & 17 & 17.5 \\
& $50-59$ years old & 4 & 4.1 \\
& Malay & 81 & 84.4 \\
& Chinese & 11 & 11.5 \\
& Indian & 4 & 4.2 \\
\hline
\end{tabular}

$N=99$ respondents

Table 5 shows the correlation, mean and standard deviation (SD) for the studied variables. The mean value for each variable has a central tendency with the distribution of $3.07-4.78$. Meanwhile, the standard deviation for every variable ranged from 0.48 to 1.08 .

Table 5: Correlations, Means and standard deviation for studied variables

\begin{tabular}{llllllll}
\hline Variables & Mean & SD & 1 & 2 & 3 & 4 & 5 \\
\hline 1. Visitor satisfaction & 4.04 & 0.48 & - & & & & \\
2. Emotional demands & 3.07 & 1.05 & 0.14 & & & & \\
3. Skill discretions & 4.12 & 0.63 & 0.10 & 0.19 & & & \\
4. Co-workers' supports & 4.21 & 0.57 & 0.08 & -0.04 & $0.41^{* * *}$ & & \\
4. Dedication & 4.78 & 0.88 & $0.26^{*}$ & 0.07 & $0.54^{* * *}$ & $0.39 * * *$ & \\
5. Absorption & 4.45 & 1.08 & $0.27^{* *}$ & $0.22^{*}$ & $0.41^{* * *}$ & $0.22^{*}$ & $0.50^{* * *}$ \\
\hline
\end{tabular}
$N=99 * p<0.05, * * p<0.01, * * * p<0.001,+p>1$

Hypothesis 1 and 2 predicted that skill discretion and coworkers' support have positive associations with dedication and absorption. According to Table 6, the multiple regression analysis was used to assess the association between two variables (skills discretion and coworkers support) towards dedication. The $R^{2}=0.42$ means that only $42 \%$ of the variance of dedication (dependent variable) can be explained by the independent variables (skills discretion and co-workers support), while the remaining $58 \%$ can be explained by other variables. Skill discretion and coworkers' support are significant with dedication where $\beta=$ 0.69 (skills discretion) and $\beta=0.31$ (co-workers' support) are at the level of $p<0.001$ and $p<0.1$. Therefore, $\mathrm{H} 1 \mathrm{a}$ and $\mathrm{H} 2 \mathrm{a}$ are supported where skills discretion and co-workers' support have associations with dedication.

Hypothesis $1 \mathrm{~b}$ and $2 \mathrm{~b}$ predicted that both job resources have associations with absorption. Table 7 shows the multiple regression results of the association between the two variables (skills discretion and co-workers support) towards absorption. The $\mathrm{R}^{2}=0.17$ means that only $17 \%$ of the variance of absorption (dependent variable) can be explained by the independent variables (skills discretion and co-workers support), while the remaining $83 \%$ can be explained by other variables. Only skill discretion is significant with absorption, where $\beta=$ 0.54 (skills discretion) and $\beta=0.06$ (co-workers' support) at the level of $p<0.01$ and $p>0.05$. Therefore, $\mathrm{H} 1 \mathrm{~b}$ is supported, and $\mathrm{H} 2 \mathrm{~b}$ is not supported. 
The next hypothesis $(\mathrm{H} 3 \& \mathrm{H} 4)$ predicted that the dedication and absorption have a direct effect on visitors' satisfaction. Table 8 shows the multiple regression results of the association between dedication and absorption towards visitors' satisfaction. The $\mathrm{R}^{2}=.017$ means that only $17 \%$ of the variance of visitors' satisfaction (dependent variable) can be explained by dedication and absorption, while the remaining $83 \%$ can be explained by other variables. Only dedication have a significant association with visitors' satisfaction where $\beta=$ 0.13 (dedication) and $\beta=0.07$ (absorption) at the level of $p<0.1 p<0.05$. Therefore, H3 is supported, while $\mathrm{H} 4$ is not supported where only dedication has an association with visitors' satisfaction.

The last hypothesis predicted that dedication mediates the relationship between skill discretion and visitors' satisfaction. Based on the findings from the Monte Carlo Mediational Simulation (Selig \& Preacher, 2008), it shows that dedication mediates the relationships between skill discretion and visitors' satisfaction (95\% The Confidence Interval (Cl), LL $=0.02429$ UL $=0.2267$ ) does not contain 0 .

Table 6: Results on the regressions analysis for dedication

\begin{tabular}{lll}
\hline \multicolumn{3}{c}{ Dedication } \\
& Step 1( $\beta)$ & Step 2( $\beta)$ \\
\hline Step 1 & & \\
Control variables & & \\
Position & $-0.57^{*}$ & $-0.34+$ \\
Ownership status & 0.14 & -0.15 \\
Education & -0.10 & 0.04 \\
Types of products & $0.26^{*}$ & 0.09 \\
& & \\
Step 2 & & \\
Main variables & & \\
Emotional demands & & -0.02 \\
Skills discretion & & $0.69 * * *$ \\
Co-workers' support & & $0.31+$ \\
& & \\
$\mathbf{R}^{2}$ & 0.14 & 0.42 \\
$\Delta \mathbf{R}^{2}$ & - & 0.28 \\
\hline
\end{tabular}

$N=99 * p<0.05, * * p<0.01, * * * p<0.001,+p>1$ 
Table 7: Results on regression analysis for absorption

\begin{tabular}{|c|c|c|}
\hline & \multicolumn{2}{|c|}{ Absorption } \\
\hline & Step 1( $\beta)$ & Step $2(\beta)$ \\
\hline \multicolumn{3}{|l|}{ Step 1} \\
\hline \multicolumn{3}{|l|}{ Control variables } \\
\hline Position & -0.29 & -0.14 \\
\hline Ownership status & 0.08 & -0.15 \\
\hline Education & -0.16 & -0.07 \\
\hline Types of products & $0.21+$ & 0.98 \\
\hline \multicolumn{3}{|l|}{ Step 2} \\
\hline \multicolumn{3}{|l|}{ Main variables } \\
\hline Emotional demands & & 0.15 \\
\hline Skills discretion & & $0.54 * *$ \\
\hline Co-workers' support & & 0.06 \\
\hline $\mathbf{R}^{2}$ & 0.06 & 0.23 \\
\hline$\Delta R^{2}$ & - & 0.17 \\
\hline
\end{tabular}

Table 8: Results on regression analysis for visitor's satisfaction

\begin{tabular}{lll} 
& \multicolumn{2}{c}{ Visitors' satisfaction } \\
& Step 1 $(\beta)$ & Step 2 $(\beta)$ \\
\hline Step 1 & & \\
Pontrol variables & & \\
Position & -0.13 & -0.08 \\
Ownership status & 0.12 & 0.09 \\
Education & -0.03 & -0.02 \\
Types of products & -0.01 & -0.05 \\
Step 2 & & \\
Main variables & & \\
Emotional demands & & 0.05 \\
Skills discretion & & -0.14 \\
Co-workers' support & & -0.02 \\
Dedication & & $0.13+$ \\
Absorption & & 0.07 \\
& & \\
$\mathbf{R}^{2}$ & 0.03 & 0.17 \\
$\Delta \mathbf{R}^{2}$ & - & 0.14 \\
\hline
\end{tabular}

$N=99 * p<0.05, * * p<0.01, * * * p<0.001,+p>1$

Conclusion and Policy Recommendation

In conclusion, consistent with the actor-partner independence model (APIM)(Bakker \& Xanthopoulou, 2009; Cook \& Kenny, 2005), the cross over between work engagement 
(dedication) and visitor satisfaction is as expected, as the dedication is the most reflected matter in the behaviour of the workers. Thus it would directly influence the satisfaction of the visitors (Yagil \& Medler-Liraz, 2014). This study contributed to the literature by providing new insight on the factors affecting visitors' satisfaction by incorporating work engagement as the alternative element. In this case, we borrowed the crossover theory (Westman \& Etzion, 1995) and APIM to explain the cross over mechanism that occurs between workers and visitors.

Both of the resources highlighted in the present study are the common job resources with regards to services. We provide evidence on the indirect effect of skill discretion on visitor satisfaction through the dedication of workers. Promoting a healthy workplace by providing opportunities in developing competencies significantly benefits not only the workers, but indirectly the customers of the organization. Adequate skill discretion opportunity can significantly improve the organizational performance through customer feedback.

Among the limitations of the present study is the limited number of respondents (dyads). While numerators managed to retrieve 99 usable and complete survey forms from the booths available, feedback from the respondents may not reflect the true answers because we approach them during working hours that might limit their respond. Future research should consider the incorporation of technology to solve such matters and to increase the rate of responses.

\section{References}

AL-Dubai, S. A. R., Qureshi, A. M., Ismail, N. H., \& Rampal, K. G. (2012). Prevalence and determinants of low back pain among taxi drivers in Malaysia. A cross sectional study. Journal of Advanced Medical Research, 2(4), 129-143.

Albrecht, S. L., \& Anglim, J. (2018). Employee engagement and emotional exhaustion of fly-infly-out workers: A diary study. Australian Journal of Psychology, 70(1), 66-75. doi: 10.1111/ajpy.12155

Allahyari, T., Saraji, G. N., Adi, J., Hosseini, M., Iravani, M., Younesian, M., \& Kass, S. J. (2008). Cognitive Failures, Driving Errors and Driving Accidents. International Journal of Occupational Safety and Ergonomics, 14(2), 149-158. doi: 10.1080/10803548.2008.11076759

Arezes, P. M., \& Miguel, A. S. (2008). Risk perception and safety behaviour: A study in an occupational environment. Safety Science, 46(6), 900-907. doi: https://doi.org/10.1016/j.ssci.2007.11.008

Bailey, J. J., Gremler, D. D., \& McCollough, M. A. (2001). Service Encounter Emotional Value. Services Marketing Quarterly, 23(1), 1-24. doi: 10.1300/J396v23n01_01

Bakker, A. B. (2009). The crossover of burnout and its relation to partner health. Stress and Health, 25(4), 343-353. doi: https://doi.org/10.1002/smi.1278

Bakker, A. B. (2014). Daily Fluctuations in Work Engagement. European Psychologist, 19(4), 227-236. doi: 10.1027/1016-9040/a000160

Bakker, A. B., \& Bal, M. P. (2010). Weekly work engagement and performance: A study among starting teachers. Journal of Occupational and Organizational Psychology, 83(1), 189206. doi: https://doi.org/10.1348/096317909X402596

Bakker, A. B., \& Demerouti, E. (2007). The job demands-resources model: State of the art. Journal of Managerial Psychology, 22(3), 309-328. doi: 10.1108/02683940710733115 
Bakker, A. B., \& Demerouti, E. (2008). Towards a model of work engagement. Career Development International, 13(3), 209-223. doi: 10.1108/13620430810870476

Bakker, A. B., Demerouti, E., \& Euwema, M. C. (2005). Job resources buffer the impact of job demands on burnout. Journal of Occupational Health Psychology, 10(2), 170.

Bakker, A. B., Demerouti, E., \& Verbeke, W. (2004). Using the job demands-resources model to predict burnout and performance. Human Resource Management, 43(1), 83-104.

Bakker, A. B., Hakanen, J. J., Demerouti, E., \& Xanthopoulou, D. (2007). Job resources boost work engagement, particularly when job demands are high. Journal of Educational Psychology, 99(2), 274. doi: http://dx.doi.org/10.1037/0022-0663.99.2.274

Bakker, A. B., Ten Brummelhuis, L. L., Prins, J. T., \& Der Heijden, F. M. M. A. v. (2011). Applying the job demands-resources model to the work-home interface: A study among medical residents and their partners. Journal of Vocational Behavior, 79(1), 170-180. doi: http://dx.doi.org/10.1016/j.jvb.2010.12.004

Bakker, A. B., \& Xanthopoulou, D. (2009). The crossover of daily work engagement: Test of an actor-partner interdependence model. Journal of Applied Psychology, 94(6), 1562 1571. doi: $10.1037 / \mathrm{a} 0017525$

Bakker Arnold, B., Westman, M., \& Hetty van Emmerik, I. J. (2009). Advancements in crossover theory. Journal of Managerial Psychology, 24(3), 206-219. doi: 10.1108/02683940910939304

Barken, R., Denton, M., Sayin, F. K., Brookman, C., Davies, S., \& Zeytinoglu, I. U. (2018). The influence of autonomy on personal support workers' job satisfaction, capacity to care, and intention to stay. Home Health Care Services Quarterly, 37(4), 294-312. doi: 10.1080/01621424.2018.1493014

Bass, B. M. (1985). Leadership: Good, better, best. Organizational Dynamics, 13(3), 26-40. doi: https://doi.org/10.1016/0090-2616(85)90028-2

Baxter, P., Lyndon, H., Dole, S., \& Battistutta, D. (2004). Less pain, more gain: Rapid skill development using old way new way. Journal of Vocational Education and Training, 56(1), 21-50. doi: 10.1080/13636820400200244

Bianchi, R., Schonfeld, I. S., \& Laurent, E. (2020). On the overlap of vital exhaustion and depression. European Psychiatry, 44, 161-163. doi: 10.1016/j.eurpsy.2017.04.007

Biswas, S., Varma, A., \& Ramaswami, A. (2013). Linking distributive and procedural justice to employee engagement through social exchange: a field study in India. The International Journal of Human Resource Management, 24(8), 1570-1587. doi: 10.1080/09585192.2012.725072

Bitner, M. J., \& Hubbert, A. R. (1994). Encounter satisfaction versus overall satisfaction versus quality :The customer's voice. Service quality: New directions in theory and practice (Vol. 34, pp. 72-94): R. T. Rust \& R. L. Olive.

Cook, W. L., \& Kenny, D. A. (2005). The Actor-Partner Interdependence Model: A model of bidirectional effects in developmental studies. International Journal of Behavioral Development, 29(2), 101-109. doi: 10.1080/01650250444000405

Crawford, E. R., LePine, J. A., \& Rich, B. L. (2010). Linking job demands and resources to employee engagement and burnout: A theoretical extension and meta-analytic test. Journal of Applied Psychology, 95(5), 834-848. doi: 10.1037/a0019364

Darian-Smith, K. (2011). Festival Places. In G. Chris \& C. John (Eds.), Chapter 2. Histories of Agricultural Shows and Rural Festivals in Australia (pp. 25-43): Channel View Publications. 
Holloway, L. (2004). Showing and telling farming: agricultural shows and re-imaging British agriculture. Journal of Rural Studies, 20(3), 319-330. doi: https://doi.org/10.1016/j.jrurstud.2003.10.002

Karasek, R. A. (1979). Job demands, job decision latitude, and mental strain: Implications job redesign. Administrative Science Quarterly, 24. doi: 10.2307/2392498

Larsen, M. H. (2017). Getting a Sense of Agriculture: Visitor Experiences from an Agricultural Fair. Sociologia Ruralis, 57(S1), 661-681. doi: https://doi.org/10.1111/soru.12158

Schaufeli, W. B., \& Bakker, A. B. (2004). Job demands, job resources, and their relationship with burnout and engagement: A multi-sample study. Journal of Organizational Behavior, 25(3), 293-315. doi: 10.1002/job.248

Schaufeli, W. B., Salanova, M., González-romá, V., \& Bakker, A. B. (2002). The Measurement of Engagement and Burnout: A Two Sample Confirmatory Factor Analytic Approach. Journal of Happiness Studies, 3(1), 71-92. doi: 10.1023/a:1015630930326

Scott, S., Si, Z., Schumilas, T., \& Chen, A. (2014). Contradictions in state- and civil societydriven developments in China's ecological agriculture sector. Food Policy, 45, 158-166. doi: https://doi.org/10.1016/j.foodpol.2013.08.002

Selig, J. P., \& Preacher, K. J. (2008). Monte Carlo method for assessing mediation: An interactive tool for creating confidence intervals for indirect effects [Computer software]. from http://quantpsy.org/.

Situma, S. P. (2012). The effectiveness of trade shows and exhibitions as organizational marketing tool (analysis of selected companies in Mombasa). International Journal of Business and Social Science, 3(22), 219-230.

Westman, M., \& Etzion, D. (1995). Crossover of stress, strain and resources from one spouse to another. Journal of Organizational Behavior, 16(2), 169-181. doi: 10.1002/job.4030160207

Xanthopoulou, D., Bakker, A. B., Demerouti, E., \& Schaufeli, W. B. (2009). Work engagement and financial returns: A diary study on the role of job and personal resources. Journal of Occupational and Organizational Psychology, 82(1), 183-200. doi: 10.1348/096317908X285633

Yagil, D., \& Medler-Liraz, H. (2014). Service Employees' Trait Authenticity and Customer Satisfaction Individual Sources, Dynamics, and Expressions of Emotion (Vol. 9, pp. 169185): Emerald Group Publishing Limited. 